\title{
Karakteristik Hidrologi dan Pengelolaannya dengan Model Hidrologi Soil and Water Assessment Tool Sub DAS Cisadane Hulu
}

\section{(Hydrological Characteristics and Management based on Hydrologic Modeling Soil and Water Assessment Tool in Cisadane Hulu Watershed)}

\author{
Widya Ulfah Utami ${ }^{1 *}$, Enni Dwi Wahjunie ${ }^{2}$, Suria Darma Tarigan ${ }^{2}$
}

(Diterima Desember 2019/Disetujui Maret 2020)

\begin{abstract}
ABSTRAK
Salah satu Daerah Aliran Sungai (DAS) prioritas untuk ditangani di Indonesia adalah DAS Cisadane karena degradasi yang tinggi. Karakteristik DAS yang terdegradasi ditandai oleh tingginya debit aliran sungai selama musim hujan dan rendahnya aliran dasar pada musim kemarau, erosi, dan sedimentasi yang tinggi. Salah satu permasalahan utama di DAS Cisadane adalah terdapat perubahan tutupan lahan yang besar di Hulu DAS Cisadane yang mengakibatkan penurunan daerah resapan air yang menyebabkan peningkatan aliran permukaan. Penelitian ini bertujuan untuk menganalisis perubahan tutupan lahan di Sub DAS Cisadane Hulu selama tahun 2013-2018 dan menganalisis kondisi DAS berdasarkan karakteristik hidrologisnya. Analisis data yang digunakan terdiri atas interpretasi citra satelit dan penggunaan model hidrologi Soil and Water Assessment Tool (SWAT). Hasil penelitian menunjukkan adanya perubahan tutupan lahan selama tahun 2013-2018. Perubahan tutupan lahan terbesar terjadi pada tutupan lahan pemukiman, yaitu sebesar 455,95 ha. Hasil simulasi skenario model SWAT menunjukkan skenario 2 merupakan skenario terbaik untuk pengelolaan Sub DAS Cisadane Hulu. Penerapan teknik Konservasi Tanah dan Air (KTA) mampu menurunkan aliran permukaan sebesar 32,1\% dan meningkatkan aliran lateral $8,89 \%$. Oleh karena itu, diharapkan hasil simulasi model SWAT ini menjadi bahan pertimbangan pemerintah daerah untuk pengelolaan Sub DAS Cisadane Hulu yang optimal.
\end{abstract}

Kata kunci: DAS Cisadane, model SWAT, perubahan tutupan lahan

\section{ABSTRACT}

One of the priority watersheds to be managed in Indonesia is the Cisadane watershed due to the high degradation problems. The Cisadene watershed degradation could be indicated by a high river flow during rainy season, low baseflow in dry season, and high erosion and sedimentation. One of the main problems in the Cisadane watershed is a huge landcover changes in the Cisadane Hulu watershed that causes a decrease in water absorption region and a surface runoff. The study aimed to analyze landcover changes in the Cisadane Hulu Watershed during 2013-2018 and analyze the watershed conditions based on their hydrological characteristics. Analysis of landcover changes patterns was carried out by processing spatial data using GIS software. Analysis for hydrological characteristics was conducted by using SWAT modelling (Soil and Water Assessment Tool). The results showed that there were land cover changes during 2013-2018. The most significant landcover changes in the Cisadane Hulu watershed was residential area (455.95 ha). The result simulation scenario of the model SWAT showed scenario 2 was the best scenario for the management of the Cisadane Hulu watershed. The application of Soil and Water Conservation can decrease surface runoff by $32.1 \%$ and increase lateral flow by $8.89 \%$. Therefore, it is expected that the results of this SWAT model simulation will be taken into consideration by the local government for the optimal management of the Cisadane Hulu watershed.

Keywords: Cisadane watershed, land cover change, SWAT modelling

\section{PENDAHULUAN}

Permasalahan utama yang dihadapi Daerah Aliran Sungai (DAS) di Indonesia pada saat ini adalah peningkatan kerusakan DAS sebagai akibat dari

1 Sekolah Pascasarjana, Program Studi Ilmu Pengelolaan Daerah Aliran Sungai, Institut Pertanian Bogor, Kampus IPB Darmaga, Bogor 16680

2 Departemen Ilmu Tanah dan Sumberdaya Lahan, Fakultas Pertanian, Institut Pertanian Bogor, Kampus IPB Darmaga, Bogor 16680

* Penulis Korespondensi: Email: widyaulfahu21@gmail.com pertambahan jumlah penduduk yang diikuti dengan peningkatan aktivitasnya. Peningkatan kerusakan DAS ini diikuti dengan pemunculan status DAS-DAS kritis di Indonesia dari tahun ke tahun (Tarigan 2009). Kerusakan DAS dicirikan dengan lahan kritis yang semakin luas yang menyebabkan fungsi DAS dalam tata air tidak optimal sehingga frekuensi dan besaran banjir dan kekeringan semakin meningkat serta urbanisasi dan tekanan populasi juga menjadi tantangan utama bagi pengelolaan sumber daya air, terutama di kota-kota di negara berkembang (Arsyad 2010; Nair et al. 2016; Trang et al. 2017). 
Seluas 24.303.294 ha lahan di Indonesia masuk ke dalam klasifikasi kritis hingga sangat kritis dan seluas 1.738.798 ha berada di wilayah DAS di Pulau Jawa (Renstra PDAS-HL 2015). Dalam renstra tersebut disebutkan sebanyak 6 DAS di Pulau Jawa masuk ke dalam DAS Prioritas, salah satunya adalah DAS Cisadane. Junaedi (2009) menyebutkan bahwa subDAS yang berpotensi menyumbang erosi terbesar di DAS Cisadane adalah unit lahan dengan tutupan lahan ladang pada kemiringan lereng $>40 \%$ dan tutupan lahan pemukiman pada kemiringan $>8 \%$. Nilda \& Merit (2015) menyatakan bahwa konversi lahan di daerah hulu DAS Cisadane menyebabkan sebagian besar air hujan yang jatuh di wilayah DAS tersebut tidak dapat diretensikan atau diserap dengan baik sehingga mengalir dengan cepat ke bagian hilir DAS, di mana peningkatan luas pemukiman mengakibatkan penurunan luasan daerah resapan air sehingga terjadi peningkatan jumlah curah hujan yang menjadi aliran permukaan. Arifasihati \& Kaswanto (2016) menambahkan sebanyak 3 variabel yang memengaruhi perubahan penggunaan dan penutupan lahan di DAS Cisadane, yaitu curah hujan, jumlah penduduk, dan jarak ke pusat kota.

Melihat berbagai permasalahan yang ada di subDAS Cisadane Hulu maka diperlukann kajian mendalam tentang kondisi hidrologi di sub-DAS Cisadane Hulu pada saat ini dan pengelolaan DAS yang direncanakan maupun telah dilakukan. Salah satu tool yang dapat menganalisis hidrologi adalah Soil and Water Assesment Tool (SWAT). SWAT dikembangkan untuk memprediksi dampak praktik-praktik manajemen lahan pada hasil air, sedimen, maupun residu kimia pertanian pada suatu DAS yang kompleks dengan berbagai jenis tanah, tutupan lahan, dan manajemen lahan pada suatu periode waktu tertentu (Arnold et al. 2012). Pola pemanfaatan sumber daya alam yang menyebabkan alih guna lahan, pemanfaatan lahan pada kawasan hutan, kejadian erosi lahan, penurunan kualitas maupun kuantitas air menjadi latar belakang pemilihan sub-DAS Cisadane Hulu sebagai daerah penelitian. Dengan demikian, penelitian ini bertujuan untuk menganalisis perubahan tutupan lahan dan pengaruh perubahan tutupan lahan pada karakteristik hidrologi sub-DAS Cisadane Hulu.

\section{METODE PENELITIAN}

\section{Lokasi Penelitian}

Penelitian ini dilaksanakan selama 1 tahun pada bulan Januari-Desember 2019 di sub-DAS Cisadane Hulu dengan luas 43,838 ha (Gambar 1). DAS Cisadane Hulu secara administrasi berada di wilayah Kabupaten dan Kota Bogor. Secara geografis, subDAS Cisadane Hulu terletak antara $106^{\circ} 44^{\prime} 30^{\prime \prime}$ $-106^{\circ} 57^{\prime} 0^{\prime \prime}$ Bujur Timur dan antara 6 $35^{\circ} 25^{\prime \prime}-6^{\circ} 46^{\prime} 30^{\prime \prime}$ Lintang Selatan.

\section{Alat dan Bahan}

Alat yang digunakan dalam penelitian ini di antaranya adalah seperangkat komputer, ArcGIS 10.1, ArcSWAT 2012, Microsoft Office 2016, pcpSTAT, dan GPS. Bahan yang digunakan di antaranya adalah data iklim, curah hujan, Citra Satelit SPOT 6 tahun 2013 dan 2018, Peta Digital Elevation Model (resolusi 8 × 8 m), karakteristik dan peta tanah, peta rupa bumi, peta batas sub-DAS Cisadane Hulu, serta peta RTRW (Rencana Tata Ruang Wilayah) Kabupaten dan Kota Bogor.

\section{Metode Analisis Data}

Analisis perubahan tutupan lahan dalam penelitian ini menggunakan analisis spasial. Analisis spasial dilakukan untuk mendapatkan peta perubahan tutupan lahan pada tahun 2013 dan 2018 menggunakan citra

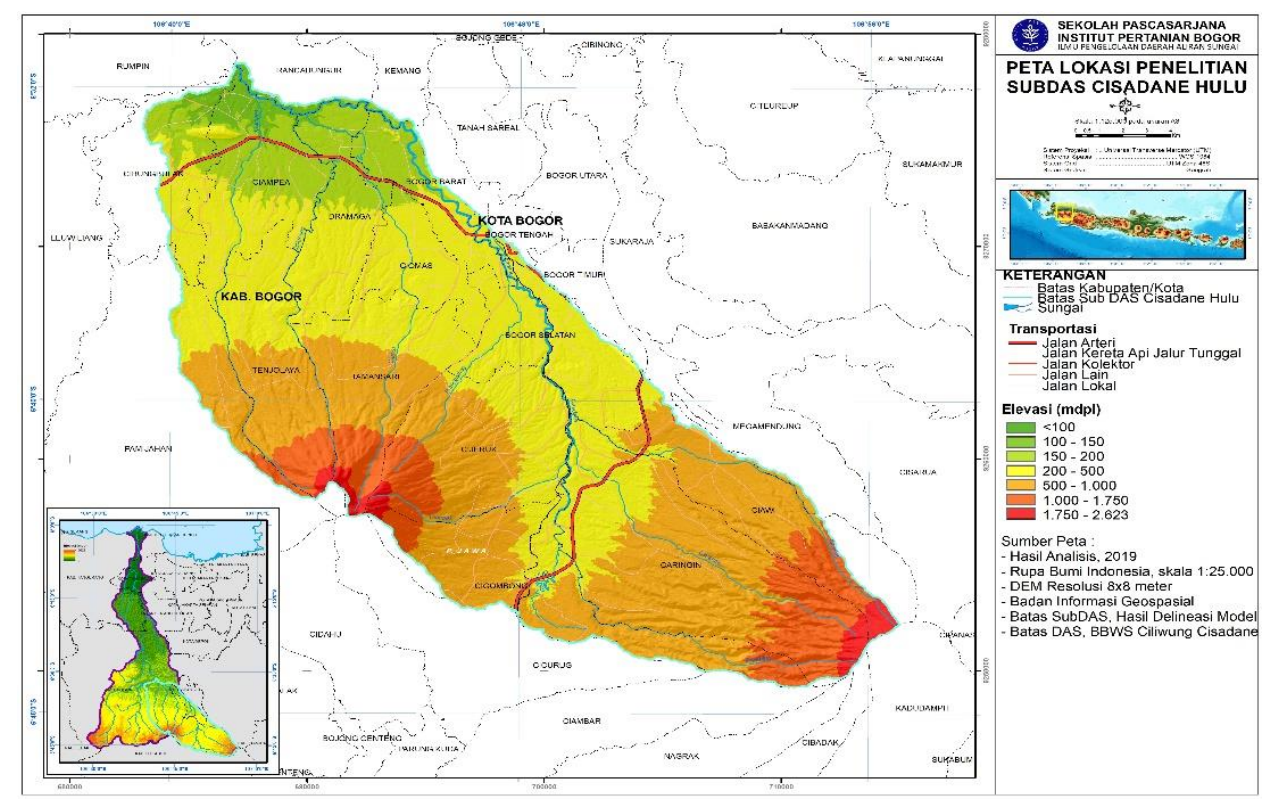

Gambar 1 Peta lokasi penelitian sub-DAS Cisadane Hulu. 

Sebelum dilakukan analisis spasial, dilakukan terlebih dahulu interpretasi citra satelit dengan on screen digitation (delineasi di layar komputer). Tujuannya adalah untuk mengklasifikasikan kelas tutupan lahan. Penentuan kelas tutupan lahan didasarkan pada peta rupa bumi Indonesia dari Badan Informasi Geospasial. Setelah dilakukan klasifikasi kelas tutupan lahan, dilakukan tumpang tindih (overlay) dari peta tutupan lahan 2013 dan 2018 untuk mendapatkan peta perubahan tutupan lahan selama 5 tahun.

\section{Parameter Input Model SWAT} DEM 8x8 m untuk delineasi DAS. Delineasi DAS dilakukan untuk penentuan jaringan sungai dan penentuan outlet DAS. Tahap selanjutnya adalah melakukan pembentukan Hydrologic Response Unit (HRU) dengan mengoverlay data tutupan lahan, tanah, dan kemiringan lereng. Input data iklim digunakan untuk input data dalam weather data definition. Selanjutnya dilakukan input data curah hujan, temperatur, kelembapan, radiasi matahari, dan kecepatan angin. Data yang telah selesai running dilakukan kalibrasi dan validasi pada model. Tujuan kalibrasi ialah untuk menyesuaikan hasil model dengan kondisi eksisting di lapangan. Metode statistik yang digunakan dalam melakukan kalibrasi adalah model efisiensi NashSutcliffe Efficiency (NSE). Persamaan Nash-Sutcliffe Efficiency (NSE) adalah sebagai berikut:

$$
N S E=1-\left[\frac{\sum_{i=1}^{n}\left(Y_{1}^{o b s}-Y_{i}^{s i m}\right)^{2}}{\sum_{i=1}^{n}\left(Y_{1}^{o b s}-\bar{Y}_{i}^{o b s}\right)^{2}}\right]
$$

Keterangan:

$Y_{1}^{\text {obs }}=$ Data observasi ke-i

$Y_{i}^{\text {sim }}=$ Data simulasi ke-i

$\bar{Y}_{i}^{\text {obs }}=$ Data observasi rata-rata

$\mathrm{n} \quad=$ Jumlah observasi

Rentang nilai NSE terletak antara $0-1$, dengan NSE $=1$ merupakan nilai optimal (Tabel 1 ). Nilai antara $0,0-1,0$ secara umum dilihat sebagai level performa satelit SPOT 6 dengan bantuan software ArcGIS 10.1.

Model SWAT diawali dengan menggunakan peta

model yang dapat diterima, sedangkan NSE $\leq 0,0$ mengindikasikan bahwa rata-rata nilai data observasi merupakan alat prediksi yang lebih baik daripada nilai data simulasi (Moriasi et al. 2007).

Untuk menganalisis kondisi DAS dalam karakteristik hidrologi sub-DAS Cisadane Hulu, dibuat 3 skenario rancangan pengelolaan DAS. Skenario yang dimaksud ialah skenario 1) Tutupan lahan berdasarkan pola ruang RTRW Kabupaten dan Kota Bogor; skenario 2) Tutupan lahan eksisting dengan penerapan teknik konservasi tanah dan air metode vegetatif; dan skenario 3) Tutupan lahan berdasarkan pada pola ruang RTRW dengan penerapan Teknik KTA. Kemudian dilakukan simulasi hasil air untuk setiap skenario dalam skala sub-DAS.

\section{HASIL DAN PEMBAHASAN}

\section{Analisis Perubahan Tutupan Lahan}

Hasil penelitian menunjukkan bahwa sub-DAS Cisadane Hulu selama tahun 2013-2018 mengalami perubahan tutupan lahan (Tabel 2). Perubahan tutupan lahan terbesar terjadi pada tutupan lahan pemukiman, yaitu seluas 455,95 ha. Tutupan lahan yang mengalami penambahan lainnya ialah tanah kosong, gedung atau bangunan, dan danau/situ masing-masing sebesar 36,$1 ; 8,4$; dan 1 ha. Tutupan lahan yang mengalami pengurangan terjadi pada tutupan lahan sawah sebanyak 258,3 ha, perkebunan sebanyak 132,4 ha, tegalan/ladang sebanyak 83,4 ha, dan semak belukar sebanyak 26 ha. Perkebunan berubah menjadi permukiman (105,2 ha) dan sawah menjadi pemukiman (209 ha). Pola perubahan tutupan lahan di masa yang akan

Tabel 1 Tingkat performa model Nash-Sutcliffe Efficiency (NSE)

\begin{tabular}{lc}
\hline \multicolumn{1}{c}{ Tingkat performa } & NSE \\
\hline Sangat baik & $0,75 \leq \mathrm{NSE} \leq 1,00$ \\
Baik & $0,65 \leq \mathrm{NSE} \leq 0,75$ \\
Memuaskan & $0,50 \leq \mathrm{NSE} \leq 0,65$ \\
Tidak memuaskan & NSE $\leq 0,50$ \\
\hline Sumber: (Moriasi et al. 2007 dalam Chaube et al. 2011).
\end{tabular}

Tabel 2 Perubahan tutupan lahan sub-DAS Cisadane Hulu 2013 dan 2018

\begin{tabular}{|c|c|c|c|}
\hline \multirow{2}{*}{ Tutupan lahan } & \multicolumn{3}{|c|}{ Luas (ha) } \\
\hline & 2013 & 2018 & Perubahan \\
\hline Danau/situ & 27,82 & 28,89 & 1,07 \\
\hline Gedung/bangunan & 135,05 & 143,49 & 8,45 \\
\hline Hutan rimba & 8398,61 & 8398,05 & $-0,56$ \\
\hline Perkebunan/kebun & 8340,68 & 8208,20 & $-132,48$ \\
\hline Pemukiman dan tempat kegiatan & 9886,17 & 10342,12 & 455,95 \\
\hline Sawah & 12330,23 & 12071,89 & $-258,33$ \\
\hline Semak belukar & 1469,83 & 1443,13 & $-26,70$ \\
\hline Sungai & 262,35 & 262,24 & $-0,10$ \\
\hline Tanah kosong/gundul & 366,42 & 402,55 & 36,13 \\
\hline Tegalan/ladang & 2621,27 & 2537,85 & $-83,42$ \\
\hline Total & 43838,43 & 43838,43 & \\
\hline
\end{tabular}


datang serupa dengan pola perubahan penggunaan lahan pada masa-masa yang telah lalu (Deng et al. 2009).

Hasil analisis kesesuaian tutupan lahan dengan pola ruang Kabupaten dan Kota Bogor menunjukkan bahwa terdapat ketidaksesuaian sebesar 3810 ha $(8,69 \%)$ dari 43838,43 ha luas sub-DAS Cisadane Hulu (Tabel 3). Ketidaksesuaian pola ruang ini banyak terdapat di wilayah sempadan sungai seluas 1737,49 ha dan kawasan pertanian seluas 1535,82 ha. Pada kawasan sempadan sungai ditemukan tutupan lahan pemukiman dan tempat kegiatan, gedung/bangunan, perkebunan, sawah, dan tegalan/ladang.

\section{Karakteristik Hidrologi Sub-DAS Cisadane Hulu Berdasarkan Model SWAT}

- Kalibrasi dan validasi debit aliran hasil model SWAT

Gambar 2 merupakan hasil kalibrasi model SWAT yang menunjukkan nilai NSE dan $\mathrm{R}^{2}$ masing-masing sebesar 0,65 dan 0,69 . Nilai NSE sebesar 0,65 dikategorikan memuaskan yang artinya model tersebut dapat diterima untuk menggambarkan kondisi hidrologis (Ridwansyah 2010). Hasil kalibrasi menunjukkan bahwa model SWAT cukup baik untuk mensimulasikan debit aliran sub-DAS Cisadane Hulu. Model SWAT memiliki hasil yang lebih baik yang dilakukan di DAS Ciliwung hulu dengan nilai $R^{2}$ dan NSE 0,70 dan 0,74 berdasarkan hasil penelitian Yustika (2012).

Hasil validasi model menunjukkan nilai $\mathrm{R}^{2}$ dan NSE yang dihasilkan masing-masing sebesar 0,65 dan 0,57 (termasuk kategori memuaskan) (Gambar 3). Berdasarkan data tersebut maka model SWAT yang digunakan konsisten dan dapat dilanjutkan untuk melakukan simulasi model. Hasil penelitian sebelumnya juga menunjukkan bahwa model SWAT cukup baik untuk mensimulasikan debit aliran sungai pada skala DAS di Indonesia, khususnya DAS Cisadane Hulu (Ridwansyah 2015; Alim 2016).

\section{Karakteristik Hidrologi Kondisi Eksisting Sub-DAS Cisadane Hulu}

Hasil analisis hidrologi pada model SWAT menunjukkan bahwa kemampuan tanah sub-DAS Cisadane

Tabel 3 Ketidaksesuaian pola ruang RT/RW Kabupaten dan Kota Bogor dengan tutupan lahan pada tahun 2018

\begin{tabular}{|c|c|c|}
\hline Pola ruang RTRW & Tutupan lahan aktual & Luas (ha) \\
\hline \multirow[t]{5}{*}{ Hutan konservasi } & Perkebunan/kebun & 169,79 \\
\hline & Pemukiman dan tempat kegiatan & 2,30 \\
\hline & Sawah & 53,41 \\
\hline & Tanah kosong/gundul & 17,54 \\
\hline & Tegalan/ladang & 36,29 \\
\hline \multirow[t]{5}{*}{ Kawasan sempadan sungai } & Gedung/bangunan & 10,04 \\
\hline & Perkebunan/kebun & 437,19 \\
\hline & Pemukiman dan tempat kegiatan & 320,39 \\
\hline & Sawah & 832,21 \\
\hline & Tegalan/ladang & 137,66 \\
\hline \multirow[t]{6}{*}{ Ruang terbuka hijau } & Perkebunan/kebun & 48,85 \\
\hline & Pemukiman dan tempat kegiatan & 16,25 \\
\hline & Sawah & 8,55 \\
\hline & Gedung/bangunan & 0,23 \\
\hline & Tegalan/ladang & 10,71 \\
\hline & Tanah kosong/gundul & 1,10 \\
\hline \multirow[t]{3}{*}{ Kawasan pertanian } & Gedung/bangunan & 19,91 \\
\hline & Pemukiman/tempat kegiatan & 1515,91 \\
\hline & Jumlah & 3810,95 \\
\hline
\end{tabular}
Jumlah



Gambar 2 Hidrograf perbandingan debit observasi dan simulasi hasil kalibrasi model (Januari-Desember 2017). 
Hulu menahan air hujan adalah sebesar $650,2 \mathrm{~mm}$ (Tabel 4). Total curah hujan yang jatuh di DAS Cisadane adalah sebesar 2083,6 mm yang menghasilkan air (water yield) sebesar $77 \%(1706,3 \mathrm{~mm})$. Dari jumlah 1706,3 mm air yang dihasilkan, sebesar $23,4 \%$ berubah menjadi surface flow, $48,9 \%$ menjadi base flow, dan 2,3\% menjadi lateral flow. Apabila dilihat dari curah hujan yang jatuh pada DAS Cisadane (2083,6 mm), sebesar $23,4 \%$ dari curah hujan tersebut berubah menjadi surface flow, $36,9 \%$ menjadi base flow, dan $27,1 \%$ menjadi lateral flow. Terlihat bahwa surface flow yang dihasilkan lebih tinggi dibandingkan dengan base flow yang menandakan bahwa fungsi hidrologi DAS Cisadane tidak baik. Hasil simulasi model SWAT untuk parameter hidrologi sub-DAS Cisadane Hulu ditampilkan pada Tabel 4.

\section{Koefisien Regim Sungai Sub DAS Cisadane Hulu}

Salah satu indikator yang menggambarkan kondisi suatu DAS yang baik dapat dilihat dari nilai koefisien regim sungai (KRS). Semakin besar nilai KRS maka kondisi DAS tersebut dapat dikatakan buruk. Sebaliknya, semakin kecil nilainya maka kondisi DAS semakin baik. Hasil penelitian menunjukkan bahwa semua skenario yang diterapkan memiliki nilai nisbah debit maksimum dan debit minimum yang lebih kecil dibandingkan dengan nilai sebelum dilakukan skenario.

Hasil simulasi skenario menunjukkan bahwa kondisi DAS yang paling baik dihasilkan oleh skenario 3 (RTRW dengan teknik KTA) dengan nilai Qmax/Qmin sebesar 3,19 (Tabel 5) yang termasuk dalam kategori sangat rendah berdasarkan kriteria yang ditetapkan oleh Dirjen RLPS (Rehabilitasi Lahan dan Perhutanan Sosial). Skenario 2 (RTRW) menghasilkan nisbah sebesar 4,04 (sangat rendah) dan skenario 1 sebesar 5,71 (rendah). Sepehri et al. (2018) menyebutkan bahwa faktor-faktor yang memengaruhi aliran sungai secara umum dapat dibagi 2, yaitu karakteristik hujan dan karakteristk DAS. Karakteristik hujan yang memengaruhi aliran sungai adalah jumlah, intensitas, lama hujan, dan distribusi hujan yang jatuh pada suatu DAS, sedangkan pengaruh karakteristik DAS ditentukan oleh ukuran, bentuk, orientasi, topografi, geologi, dan penggunaan lahan.

Aliran Permukaan, Aliran Lateral, dan Aliran Dasar

Hasil penelitian menunjukkan bahwa skenarioskenario yang diterapkan secara umum dapat

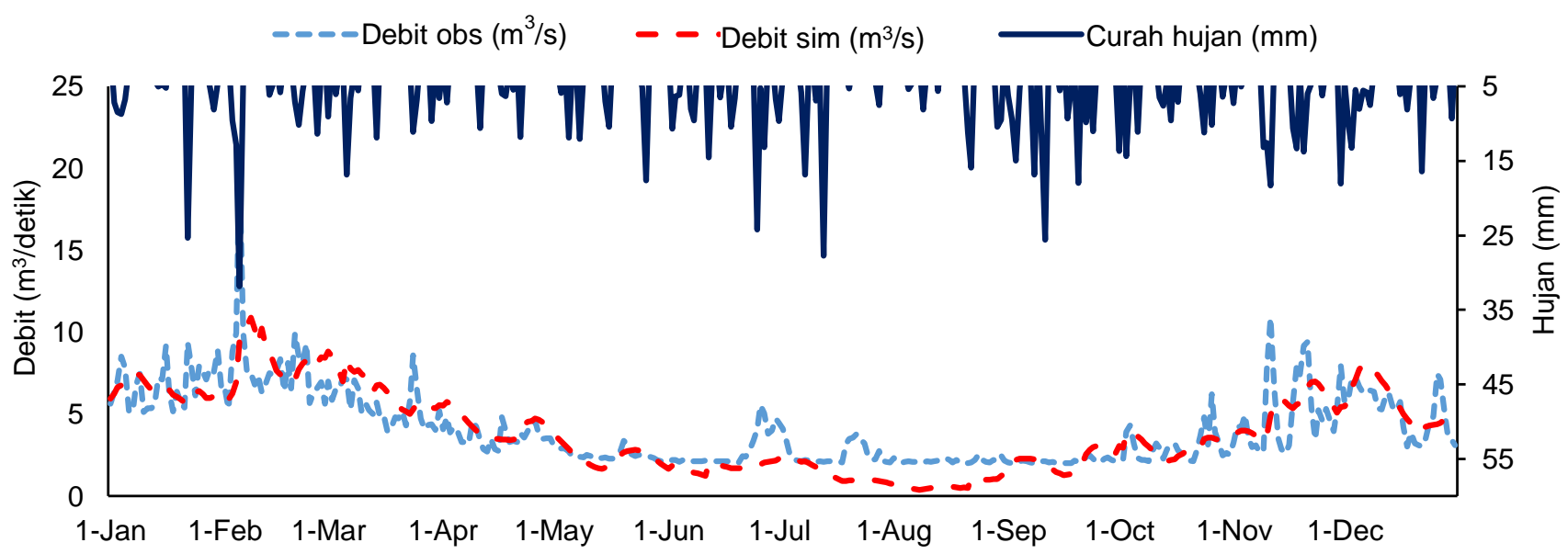

Gambar 3 Hidrograf debit hasil validasi model (Januari-Desember 2018).

Tabel 4 Hasil simulasi model Soil and Water Assessment Tool (SWAT) untuk parameter hidrologi sub-DAS Cisadane Hulu

\begin{tabular}{|c|c|c|c|c|c|c|c|c|c|}
\hline \multirow{2}{*}{ Bulan } & \multirow{2}{*}{$\begin{array}{r}\text { PREC } \\
\mathrm{mm}\end{array}$} & \multicolumn{2}{|c|}{ SURQ } & \multicolumn{2}{|c|}{ LATQ } & \multicolumn{2}{|c|}{ GWQ } & \multirow{2}{*}{$\frac{\mathrm{SW}}{\mathrm{Mm}}$} & \multirow{2}{*}{$\begin{array}{r}\text { Water yield } \\
\mathrm{mm}\end{array}$} \\
\hline & & $\mathrm{mm}$ & $\%$ hujan & $\mathrm{mm}$ & \% hujan & $\mathrm{mm}$ & $\%$ hujan & & \\
\hline Januari & 136,9 & 26,2 & 19,2 & 45,7 & 33,4 & 88,0 & 64,2 & 651,5 & 152,9 \\
\hline Februari & 179,0 & 26,5 & 14,8 & 67,2 & 37,6 & 70,6 & 39,4 & 650,5 & 155,0 \\
\hline Maret & 115,0 & 13,4 & 11,7 & 38,4 & 33,4 & 58,5 & 50,9 & 646,9 & 108,0 \\
\hline April & 162,5 & 33,6 & 20,7 & 47,5 & 29,2 & 47,1 & 29,0 & 649,2 & 112,7 \\
\hline Mei & 198,1 & 55,9 & 28,2 & 48,8 & 24,6 & 58,4 & 29,4 & 651,8 & 135,1 \\
\hline Juni & 158,6 & 42,8 & 27,0 & 39,2 & 24,7 & 62,9 & 39,6 & 651,5 & 126,8 \\
\hline Juli & 204,2 & 82,5 & 40,4 & 39,0 & 19,1 & 65,9 & 32,3 & 645,4 & 148,4 \\
\hline Agustus & 154,5 & 43,0 & 27,8 & 33,5 & 21,7 & 71,8 & 46,5 & 635,4 & 129,4 \\
\hline September & 127,4 & 23,8 & 18,6 & 23,6 & 18,5 & 47,3 & 37,1 & 616,4 & 83,8 \\
\hline Oktober & 241,3 & 50,8 & 21,0 & 62,1 & 25,7 & 56,4 & 23,4 & 642,3 & 145,4 \\
\hline November & 222,0 & 51,6 & 23,3 & 65,7 & 29,6 & 68,1 & 30,7 & 650,1 & 161,1 \\
\hline Desember & 184,1 & 38,2 & 20,7 & 54,5 & 29,6 & 73,4 & 39,9 & 650,2 & 147,6 \\
\hline Total & 2083,6 & 493,7 & 23,4 & 565,2 & 27,1 & 768,2 & 36,9 & 650,2 & 1706,3 \\
\hline
\end{tabular}

Keterangan: PREC = Curah hujan; SURQ = Surface flow; LATQ = Lateral flow; GWQ = Base flow; SW = Simpanan air tanah; dan Water Yield = hasil air. 
Tabel 5 Koefisien regim sungai sub-DAS Cisadane Hulu

\begin{tabular}{lcccr}
\hline & Kondisi eksisting & Skenario 1 & Skenario 2 & Skenario 3 \\
\hline Qmax $\left(\mathrm{m}^{3}\right.$ det $\left.^{-1}\right)$ & 38,31 & 30,74 & 33,41 & 29,92 \\
Qmin $\left(\mathrm{m}^{3}\right.$ det $\left.^{-1}\right)$ & 2,21 & 5,38 & 8,27 & 9,40 \\
Qmax/Qmin & 17,33 & 5,71 & 4,04 & 3,19 \\
Kategori & Tinggi & Rendah & Sangat rendah & Sangat rendah \\
\hline
\end{tabular}

Tabel 6 Karakteristik hidrologi sub-DAS Cisadane Hulu pada berbagai skenario yang diterapkan pada tahun 2018

\begin{tabular}{|c|c|c|c|c|c|c|c|}
\hline \multirow{2}{*}{ Karakteristik hidrologi } & \multirow{2}{*}{$\begin{array}{c}\text { Eksisting } \\
\mathrm{mm}\end{array}$} & \multicolumn{2}{|c|}{ Skenario 1} & \multicolumn{2}{|c|}{ Skenario 2} & \multicolumn{2}{|c|}{ Skenario 3} \\
\hline & & $\mathrm{mm}$ & $\Delta(\%)$ & $\mathrm{mm}$ & $\Delta(\%)$ & $\mathrm{mm}$ & $\Delta(\%)$ \\
\hline Curah hujan & 1160,35 & 1160,35 & & 1160,35 & & 1160,35 & \\
\hline Aliran permukaan & 343,46 & 394,31 & 14,81 & 233,23 & $-32,1$ & 312,51 & $-9,01$ \\
\hline Aliran lateral & 420,93 & 406,39 & $-3,45$ & 458,36 & 8,89 & 437,15 & 3,85 \\
\hline Aliran dasar & 551,75 & 562,13 & 1,88 & 570,69 & 3,43 & 554,04 & 0,42 \\
\hline
\end{tabular}

menurunkan aliran permukaan (surface run off) (Tabel 6). Penerapan skenario RTRW (skenario 1) mengacu pada arahan kebijakan tata ruang peta RTRW yang bersifat menyeluruh dan mengatur arahan pembangunan pusat-pusat kegiatan di suatu wilayah. Output hasil simulasi skenario 1 menaikkan aliran permukaan (surface run off) sebesar 50,85 $\mathrm{mm}$ atau meningkat sebesar $15 \%$ dibandingkan dengan kondisi eksisting. Terjadi penurunan aliran permukaan pada skenario 2 sebesar $32 \%$ yang disertai dengan peningkatan aliran lateral sebesar $37,43 \mathrm{~mm}$ atau sebesar $9 \%$ dari kondisi eksisting. Aliran bawah tanah meningkat sebesar $18,94 \mathrm{~mm}$ atau sebesar 3,43\%. Pada skenario 3 (RTRW dengan Teknik KTA) juga terjadi peningkatan aliran lateral sebesar 16,22 mm atau sebesar $3,85 \%$ dan aliran bawah tanah sebesar 2,29 $\mathrm{mm}$ atau sebesar $0,42 \%$ serta menurunkan nilai aliran permukaan sebesar 9,01\%. Munggaran (2017) menerapkan simulasi RTRW di DAS Cimanuk Hulu. Hasil penelitiannya menunjukkan bahwa terjadi penurunan aliran permukaan sebesar $45 \%$. Hal ini terjadi karena adanya peningkatan luasan Kawasan hutan lindung dan hutan konservasi.

Penerapan teknik konservasi tanah dan air (skenario 2) metode vegetatif berupa penerapan strip cropping mampu menurunkan aliran permukaan sebesar 110,23 $\mathrm{mm}$ atau sebesar $32,1 \%$ dan terjadi peningkatan aliran lateral sebesar $8,89 \%$. Hal ini terjadi karena kondisi hutan di sub-DAS Cisadane Hulu relatif tetap jumlahnya atau tidak berkurang. Hasil ketiga skenario menunjukkan skenario 2 merupakan skenario terbaik untuk pengelolaan sub-DAS Cisadane Hulu. Penerapan strip cropping dapat menurunkan aliran permukaan sampai 13\% (Jeong et al. 2010). Hasil penelitian Yustika et al. (2012) menunjukkan bahwa kombinasi penerapan teknologi konservasi tanah penanaman strip di lahan kebun campuran dan agroforestri di lahan perkebunan teh dapat menghambat aliran permukaan sebesar $51-57 \%$.

\section{KESIMPULAN}

Perubahan tutupan lahan pemukiman yang cukup signifikan telah menyebabkan peningkatan aliran permukaan dan menurunkan fungsi hidrologi DAS. Terdapat perubahan tutupan Iahan selama tahun 2013-2018. Perubahan terbesar terjadi pada penambahan tutupan lahan pemukiman, yaitu sebesar 455,95 ha. Penggunaan lahan yang mengalami penambahan lainnya ialah tanah kosong, gedung atau bangunan, dan danau/situ masing-masing sebesar 36,1; 8,4; dan 1 ha. Penerapan skenario terbaik untuk pengelolaan sub-DAS Cisadane Hulu ialah skenario penerapan lahan eksisting dengan teknik KTA (skenario 2). Tenik KTA mampu menurunkan aliran permukaan sebesar $32,1 \%$ dan meningkatkan aliran lateral (lateral flow) sebesar $8,89 \%$. Oleh karena itu, untuk meminimalkan laju aliran permukaan akibat dampak perubahan tutupan lahan, perlu dilakukan penghutanan kembali kawasan sempadan sungai yang dikombinasikan dengan penerapan Teknik KTA dan penghutanan kembali lahan pertanian milik rakyat.

\section{DAFTAR PUSTAKA}

Alim N. 2016. Uji sensitivitas model SWAT terhadap data spasial dengan resolusi yang berbeda (Studi Kasus: Sub-DAS Cisadane Hulu, Jawa Barat). [Tesis]. Sekolah Pascasarjana. Bogor (ID): Institut Pertanian Bogor.

Arifasihati Y, Kaswanto. 2016. Analysis of land use and cover changes in Ciliwung and Cisadane Watershed in three decades. Procedia Environmental Sciences. 33: 465-469. https:// doi.org/10.1016/j.proenv.2016.03.098

Arsyad S. 2010. Konservasi Tanah dan Air. Edisi kedua. Bogor (ID): IPB Press.

Arnold JG, Moriasi DN, Gassman PW, Abbaspour KC, White MJ, Srinivasan R, Santhi C, Harmel RD, van Griensven A, Van Liew MW. 2012. SWAT: Model Use, Calibration and Validation. Transaction of ASABE (American Society of Agricultural and Biological Engineers. 55(4): 1491-1508. https:// doi.org/10.13031/2013.42256

Chaube UC, Suryavanshi S, Nurzaman L, Pandey A. 2011. Synthesis of flow series of tributaries in upper 
Betwa basin. Internaional Journal of Environmental Science. 1(7): 1459-1475.

Deng JS, Wang K, Hong Y, Qi JG. 2009. Spatio Temporal Dynamics and Evolution of Land Use Change and Landscape Pattern in Response to Rapid Urbanization. Landscape and Urban Planning. 92: 187-198. https://doi.org/10.1016/ j.landurbplan.2009.05.001

[Ditjen RLPS] Direktorat Jenderal Rehabilitasi Lahan dan Perhutanan Sosial. 2014. Peraturan Direktur Jenderal Rehabilitasi Lahan dan Perhutanan Sosial Nomor: P.61 /Menhut-II/2014 tentang Monitoring dan Evaluasi Daerah Aliran Sungai. Jakarta (ID).

[Ditjen PDAS-HL] Direktorat Jenderal Pengelolaan Daerah Aliran Sungai dan Hutan Lindung. Pengendalian Daerah Aliran Sungai dan Hutan Lindung Kementerian Lingkungan Hidup dan Kehutanan. 2015. Rencana Strategis Direktorat Jenderal Pengendalian Daerah Aliran Sungai dan Hutan Lindung Tahun 2015-2019. Jakarta (ID).

Jeong J, Kannan N, Arnold JG, Glick R, Gosselink L, Srininvasan R. 2010. Development and integration of subhourly rainfall-runoff modeling capability within a watershed model. Water Resource Management. 24(15): 4505-4527. https://doi.org/ 10.1007/s112 69-010-9670-4

Junaedi E. 2009. Kajian Berbagai Alternatif Perencanaan Pengelolaan DAS Cisadane Menggunakan Model SWAT [Tesis]. Sekolah Pascasarjana. Bogor (ID): Institut Pertanian Bogor.

Munggaran G. 2017. Analisis Respons Hidrologi dan Simulasi Teknik Konservasi Tanah dan Air Sub DAS Cimanuk Hulu [Tesis]. Sekolah Pascasarjana. Bogor (ID): Institut Pertanian Bogor.

Moriasi DN, Arnold JG, Van Liew MW, Bingner RD, Harmel RD and Veith TL. 2007. Model evaluation guidelines for systematic quantification of accuracy in watershed simulations. Transactions of the ASABE. 50(3): 885-900. https://doi.org/ $10.13031 / 2013.23153$
Nilda IWS, Merit IN. 2015. Analisis perubahan tutupan lahan dan dampaknya terhadap hasil air di DAS Cisadane Hulu. Ecotrophic. 9(1): 35-45. https:// doi.org/10.24843/EJES.2015.v09.i01.p05

Ridwansyah I. 2010. Applying SWAT and GIS to Predict impact of Landuse Change to Water Yield and Landuse Optimizing in Upper Cimanuk Catchment Area. [Tesis]. Bogor (ID): Institut Pertanian Bogor.

Ridwansyah I. 2015. Analisis dampak Perubahan Tutupan lahan terhadap Respons Hidrologi DAS Cisadane Menggunakan Model CLUE-S Dan SWAT. [Dissertaion]. Sekolah Pascasarjana. Bogor (ID): Institut Pertanian Bogor.

Sepehri M, Malekinezhad H, Ilderomi AR, Talebi A, Hosseini SZ. 2018. Studying the effect of rain water harvesting from roof surfaces on runoff and household consumption reduction. Sustainable Cities and Society. 43: 317-324. https://doi.org/ 10.1016/j.scs.2018.09.005

Trang NTT, Shrestha S, Shrestha M, Datta A, Kawasaki A. 2017. Evaluating the impacts of climate and land-use change on the hydrology and nutrient yield in a transboundary river basin: a case study I the 3S river basin (Sekong, Sesan, and Srepok). Science of the Total Environmental. 576: 586-598. https://doi.org/10.1016/j.scitotenv. 2016.10.138

Tarigan SD. 2009. Pengembangan Informasi Spasial Berbasis Web (Web GIS) untuk Sinergi Rehabilitasi DAS Kritis Nasional. Prosiding Seminar Nasional Himpunan Informatika Pertanian Indonesia. ISBN: 978-979-95366-0-7. Bogor (ID): Institut Pertanian Bogor.

Yustika RD, Tarigan SD, Hidayat Y, Sudadi U. 2012. Simulasi manajemen lahan di das Ciliwung Hulu menggunakan model SWAT. Jurnal Informatika Pertanian. 21(2): 71-79. https:// doi.org/10.21082/ip.v21n2.2012.p71-79 